\section{TUGAS DAN WEWENANG PEMERINTAH DALAM MELAKSANAKAN PENANGANAN FAKIR MISKIN MENURUT UNDANG-UNDANG NOMOR 13 TAHUN 2011 TENTANG PENANGANAN FAKIR MISKIN ${ }^{1}$ Oleh : Cella Mokat ${ }^{2}$}

\begin{abstract}
ABSTRAK
Penelitian ini dilakukan dengan tujuan untuk mengetahui bagaimana tugas pemerintah dalam melaksanakan penanganan fakir miskin dan bagaimana wewenang pemerintah dalam melaksanakan penanganan fakir miskin. Dengan menggunakan metode peneltian yuridis normatif, disimpulkan: 1. Tugas pemerintah dalam melaksanakan penanganan fakir miskin diantaranya memberdayakan pemangku kepentingan dalam penanganan fakir miskin dan memfasilitasi dan mengoordinasikan pelaksanaan kebijakan dan strategi penanganan fakir miskin. Pemerintah Daerah Provinsi bertugas mengawasi dan mengendalikan pelaksanaan kebijakan, strategi, dan program dalam penanganan fakir miskin lintaskabupaten/kota dan mengevaluasi pelaksanaan kebijakan, strategi, dan program penyelenggaraan penanganan fakir miskin lintaskabupaten/kota. Pemerintah Daerah Kabupaten/Kota bertugas memfasilitasi, mengoordinasikan, dan menyosialisasikan pelaksanaan kebijakan, strategi, dan program penyelenggaraan penanganan kemiskinan, dengan memperhatikan kebijakan provinsi dan kebijakan nasional dan melaksanakan pemberdayaan pemangku kepentingan dalam penanganan fakir miskin pada tingkat kabupaten/kota. 2. Wewenang pemerintah dalam melaksanakan penanganan fakir miskin seperti menetapkan kebijakan dan strategi penanganan fakir miskin pada tingkat nasional. Pemerintah daerah provinsi berwenang menetapkan kebijakan, strategi, dan program tingkat provinsi dalam bentuk rencana penanganan fakir miskin di daerah dengan berpedoman pada kebijakan, strategi, dan program nasional. Pemerintah daerah kabupaten/kota berwenang menetapkan kebijakan, strategi, dan program tingkat
\end{abstract}

\footnotetext{
${ }^{1}$ Artikel Skripsi. Dosen Pembimbing: Harly Stanly Muaja, SH., MH; Dr. Josepus J. Pinori, SH., MH

2 Mahasiswa pada Fakultas Hukum Unsrat, NIM. 16071101545
}

kabupaten/kota dalam bentuk rencana penanganan fakir miskin di daerah dengan berpedoman pada kebijakan, strategi, dan program nasional. Pemerintah desa melaksanakan penanganan fakir miskin sesuai dengan ketentuan peraturan perundangundangan.

Kata kunci: Tugas Dan Wewenang, Pemerintah, Penanganan Fakir Miskin.

\section{PENDAHULUAN}

\section{A. Latar Belakang}

Tujuan negara sebagaimana diamanatkan dalam Pembukaan UndangUndang Dasar Negara Republik Indonesia Tahun 1945 adalah melindungi segenap bangsa Indonesia dan seluruh tumpah darah Indonesia, memajukan kesejahteraan umum, mencerdaskan kehidupan bangsa, dan ikut melaksanakan ketertiban dunia berdasarkan kemerdekaan, perdamaian abadi, dan keadilan sosial.

Memajukan kesejahteraan umum, mencerdaskan kehidupan bangsa, dan keadilan sosial bagi seluruh rakyat Indonesia, Negara berkewajiban mensejahterakan seluruh warga negaranya dari kondisi kefakiran dan kemiskinan sebagaimana diamanatkan dalam Pembukaan Undang-Undang Dasar Negara Republik Indonesia Tahun 1945. Kewajiban negara dalam membebaskan dari kondisi tersebut dilakukan melalui upaya penghormatan, perlindungan, dan pemenuhan hak atas kebutuhan dasar. Upaya tersebut harus dilakukan oleh negara sebagai prioritas utama dalam pembangunan nasional termasuk untuk mensejahterakan fakir miskin. ${ }^{3}$

Landasan hukum bagi upaya mensejahterakan fakir miskin sampai saat ini masih bersifat parsial yang tersebar di berbagai ketentuan peraturan perundang-undangan, sehingga diperlukan adanya undangundang yang secara khusus mengatur fakir miskin. Dengan adanya undang-undang yang secara khusus mengatur fakir miskin, diharapkan memberikan pengaturan yang bersifat komprehensif dalam upaya mensejahterakan fakir miskin yang lebih terencana, terarah, dan berkelanjutan.

Materi pokok yang diatur dalam UndangUndang ini, antara lain Hak dan Tanggung

\footnotetext{
3 Penjelasan Atas Undang-Undang Nomor 13 Tahun 2011 Tentang Penanganan Fakir Miskin.
} 
Jawab, Penanganan Fakir Miskin, Tugas dan Wewenang, Sumber Daya, Koordinasi dan Pengawasan, Peran Serta Masyarakat, dan Ketentuan Pidana. Undang-Undang ini diharapkan dapat memberikan keadilan sosial bagi warga negara untuk dapat hidup secara layak dan bermartabat. ${ }^{4}$

Masalah Kemiskinan masih menjadi salah satu permasalahan utama bagi negara-negara berkembang termasuk Indonesia, sebagai salah satu negara berkembang isu kemiskinan ini perlu dituntaskan. Upaya penanggulangan kemiskinan terus dilakukan oleh Pemerintah, dan telah dilaksanakan sejak tahun 1970-an hingga sekarang namun belum mampu menuntaskan masalah kemiskinan.

Selain itu penanggulangan kemiskinan juga berkaitan dengan dimensi Pembangunan, Pemerataan dan Kewilayahan dengan prioritas pada upaya pemerataan antar kelompok pendapatan, pengurangan kesenjangan pembangunan antarwilayah. Program-program pembangunan dalam dimensi ini merupakan penjabaran dari Cita Ketiga yaitu membangun Indonesia dari pinggiran dengan memperkuat daerah-daerah dan desa dalam kerangka negara kesatuan, Cita Kelima yaitu meningkatkan kualitas hidup manusia Indonesia, dan Cita Keenam yaitu meningkatkan produktivitas rakyat dan daya saing di pasar Internasional. Dalam dimensi ini penanggulangan kemiskinan bermaksud meminimalkan kesenjangan pembangunan antar kelompok pendapatan dan antar daerah. ${ }^{5}$

Pada dasarnya pengentasan kemiskinan tidak hanya menjadi tanggung jawab pemerintah semata, tetapi diperlukan juga kesadaran dan kemauan yang kuat serta tanggung jawab dari masyarakat miskin itu sendiri untuk berupaya bagaimana meningkatkan pendapatan. Pemerintah telah banyak merumuskan program-program pengentasan kemiskinan, namun diperlukan merumuskan kembali sasaran kebijakan strategis apa untuk mempercepat penurunan kemiskinan. Untuk mencapai sasaran tersebut, Kementerian Hukum dan HAM RI memandang perlu melakukan analisis dan evaluasi hukum agar penanganan penanggulangan kemiskinan

4Penjelasan Atas Undang-Undang Nomor 13 Tahun 2011

Tentang Penanganan Fakir Miskin.

5 Ibid. hlm. 3. dapat dilaksanakan sesuai arah kebijakan pembangunan sebagaimana tergambar dalam RPJMN 2015-2919. Analisis dan evaluasi hukum merupakan bagian dari konsep pengujian peraturan perundang-undangan (executive review) yang selama ini belum begitu dikenal dalam praktik ketatanegaraan dibandingkan dengan konsep yudicial rewiew, atau legislative review. ${ }^{6}$

\section{B. Rumusan Masalah}

1. Bagaimanakah tugas pemerintah dalam melaksanakan penanganan fakir miskin ?

2. Bagaimanakah wewenang pemerintah dalam melaksanakan penanganan fakir miskin?

\section{Metode Penelitian}

Penelitian hukum yang dilakukan dengan cara meneliti bahan pustaka atau data sekunder belaka, dapat dinamakan penelitian hukum normatif atau penelitian hukum kepustakaan (di samping adanya penelitian hukum sosiologis atau empiris yang terutama meneliti data primer). ${ }^{7}$ Penelitian hukum normatif digunakan dalam menyusun penulisan ini. Metode penelitian hukum normatif menggunakan bahan-bahan hukum yang dikumpulkan melalui studi kepustakaan.

\section{PEMBAHASAN}

\section{A. Tugas Pemerintah Dalam Melaksanakan Penanganan Fakir Miskin}

Undang-Undang Nomor 13 Tahun 2011 Tentang Penanganan Fakir Miskin. Pasal 28 Dalam pelaksanaan penanganan fakir miskin, Pemerintah bertugas:

a. memberdayakan pemangku kepentingan dalam penanganan fakir miskin;

b. memfasilitasi dan mengoordinasikan pelaksanaan kebijakan dan strategi penanganan fakir miskin;

c. mengawasi dan mengendalikan pelaksanaan kebijakan dan strategi dalam penanganan fakir miskin;

d. mengevaluasi kebijakan dan strategi penyelenggaraan penanganan fakir miskin;

\footnotetext{
6 Ibid. hlm. 5.

${ }^{7}$ Soerjono Soekanto dan Sri Mamudji, Penelitian Hukum Normatif Suatu Tinjauan Singkat, PT Raja Grafindo Persada, Jakarta. 1995, hlm. 13-14.
} 
e. menyusun dan menyediakan basis data fakir miskin; dan

f. mengalokasikan dana yang memadai dan mencukupi dalam Anggaran Pendapatan dan Belanja Negara untuk penyelenggaraan penanganan fakir miskin.

Undang-Undang Nomor 23 Tahun 2014

Tentang Pemerintahan Daerah. Pasal 1 angka 2. Pemerintahan Daerah adalah penyelenggaraan urusan pemerintahan oleh pemerintah daerah dan dewan perwakilan rakyat daerah menurut asas otonomi dan tugas pembantuan dengan prinsip otonomi seluas-luasnya dalam sistem dan prinsip Negara Kesatuan Republik Indonesia sebagaimana dimaksud dalam Undang-Undang Dasar Negara Republik Indonesia Tahun 1945.

Secara makro tingkat kemiskinan Indonesia terus mengalami penurunan meskipun penurunananya melambat. BPS merilis tingkat kemiskinan nasional terbaru pada bulan Maret 2016 masih pada level 10,86\% atau lebih 28 juta penduduk dari total penduduk, atau hanya turun kurang dari $2 \%$ dari kondisi 5 tahun lalu yaitu Maret 2011 yang sudah mencapai 12, $49 \%$. Isu kemiskinan ini erat kaitannya dengan persoalan ketimpangan atau kesenjangan, baik ketimpangan tingkat kesejahteraan (antar kelompok pendapatan) maupun ketimpangan antarwilayah. 8 Dalam konteks upaya penanggulangan kemiskinan, pada periode sebelum dan sesudah reformasi, adalah pada adanya instrumen untuk mendukung prioritas pembangunan yang meliputi berbagai kebijakan, baik berupa peraturan perundangundangan, peraturan pemerintah, peraturan presiden, instruksi presiden maupun peraturan menteri terkait sampai dengan peraturan daerah. Namun demikian, perbedaan mendasar dari kebijakan pemerintah pra reformasi dan pasca reformasi adalah dalam hal pendekatan program.

Upaya penanggulangan kemiskinan di masa lalu cenderung bersifat project oriented dan sektoral berdasarkan instruksi khusus dari presiden, misalnya melalui Inpres Desa Tertinggal (IDT), sehingga sulit untuk

\footnotetext{
${ }^{8}$ Pusat Analisis Dan Evaluasi Hukum Nasional Badan Pembinaan Hukum Nasional Kementerian Hukum Dan Ham. Op.Cit. hlm. 19 (Lihat Perbandingan Tingkat Kemiskinan dan Ketimpangan Indonsia 1980-2014, BPS, Susenas dan Vivi Alatas (Perhitungan Bank Dunia, 2014).
}

mempertahankan keberlanjutannya. Kebijakan pasca reformasi ditandai dengan dikembangkannya pendekatan program secara nasional dan lintas sektor dengan kerangka kebijakan dan graduasi yang lebih jelas melalui pengembangan strategi khusus dan target kepada kelompok masyarakat miskin. ${ }^{9}$

Undang-Undang Nomor 13 Tahun 2011 Tentang Penanganan Fakir Miskin. Pemerintah Daerah Provinsi. Pasal 30 ayat:

(1) Dalam pelaksanaan penanganan fakir miskin, pemerintah daerah provinsi bertugas:

a. memberdayakan pemangku kepentingan dalam penanganan fakir miskin lintaskabupaten/kota;

b. memfasilitasi, mengoordinasi, serta menyosialisasikan pelaksanaan kebijakan dan strategi penanganan fakir miskin lintaskabupaten/kota;

c. mengawasi dan mengendalikan pelaksanaan kebijakan, strategi, dan program dalam penanganan fakir miskin lintaskabupaten/kota;

d. mengevaluasi pelaksanaan kebijakan, strategi, dan program penyelenggaraan penanganan fakir miskin lintaskabupaten/kota; dan

e. mengalokasikan dana yang memadai dan mencukupi dalam anggaran pendapatan dan belanja daerah untuk penyelenggaraan penanganan fakir miskin.

Pemerintah Daerah Kabupaten/Kota. Pasal 31 ayat:

(1) Dalam penyelenggaraan penanganan fakir miskin, pemerintah daerah kabupaten/kota bertugas:

a. memfasilitasi, mengoordinasikan, dan menyosialisasikan pelaksanaan kebijakan, strategi, dan program penyelenggaraan penanganan kemiskinan, dengan memperhatikan kebijakan provinsi dan kebijakan nasional;

b. melaksanakan pemberdayaan pemangku kepentingan dalam penanganan fakir miskin pada tingkat kabupaten/kota;

c. melaksanakan pengawasan dan pengendalian terhadap kebijakan,

\footnotetext{
9 Ibid. hlm. 20
} 
strategi, serta program dalam penanganan fakir miskin pada tingkat kabupaten/kota;

d. mengevaluasi kebijakan, strategi, dan program pada tingkat kabupaten/kota;

e. menyediakan sarana dan prasarana bagi penanganan fakir miskin;

f. mengalokasikan dana yang cukup dan memadai dalam anggaran pendapatan dan belanja daerah untuk menyelenggarakan penanganan fakir miskin.

\section{B. Wewenang Pemerintah Dalam Melaksanakan Penanganan Fakir Miskin}

Peraturan Pemerintah Republik Indonesia Nomor 63 Tahun 2013 Tentang Pelaksanaan Upaya Penanganan Fakir Miskin Melalui Pendekatan Wilayah. Pasal 1 angka 1. Fakir Miskin adalah orang yang sama sekali tidak mempunyai sumber mata pencaharian dan/atau mempunyai sumber mata pencaharian tetapi tidak mempunyai kemampuan memenuhi kebutuhan dasar yang layak bagi kehidupan dirinya dan/atau keluarganya.

Pasal 1 angka 2. Penanganan Fakir Miskin adalah upaya yang terarah, terpadu, dan berkelanjutan yang dilakukan Pemerintah, Pemerintah Daerah, dan/atau masyarakat dalam bentuk kebijakan, program dan kegiatan pemberdayaan, pendampingan, serta fasilitasi untuk memenuhi kebutuhan dasar setiap warga negara. Pasal 2 ayat (1) Pemerintah dan Pemerintah Daerah bertanggungjawab terhadap pelaksanaan Penanganan Fakir Miskin. Ayat (2) Masyarakat berperan serta dalam pelaksanaan Penanganan Fakir Miskin yang dilaksanakan sesuai dengan ketentuan peraturan perundang-undangan.

Pemerintah yaitu:

1. sistem menjalankan wewenang dan kekuasaan mengatur kehidupan sosial, ekonomi dan politik suatu negara atau bagian-bagiannya;

2. sekelompok orang yang secara bersamasama memikul tanggung jawab terbatas untuk menggunakan kekuasaan;

3. penguasaan suatu negara (bagian negara);

4. badan tertinggi yang memerintah suatu negara (seperti cabinet merupakan sesuatu pemerintah);
5. negara atau negeri (sebagai lawan partikelir atau swasta). ${ }^{10}$

Undang-Undang Nomor 13 Tahun 2011 Tentang Penanganan Fakir Miskin. Pasal 29. Dalam melaksanakan tugas sebagaimana dimaksud dalam Pasal 28 Pemerintah berwenang menetapkan kebijakan dan strategi penanganan fakir miskin pada tingkat nasional.

Pasal 30 ayat (2) Dalam melaksanakan tugas sebagaimana dimaksud pada ayat (1), pemerintah daerah provinsi berwenang menetapkan kebijakan, strategi, dan program tingkat provinsi dalam bentuk rencana penanganan fakir miskin di daerah dengan berpedoman pada kebijakan, strategi, dan program nasional.

Pasal 31 ayat (2) Dalam melaksanakan tugas sebagaimana dimaksud pada ayat (1), pemerintah daerah kabupaten/kota berwenang menetapkan kebijakan, strategi, dan program tingkat kabupaten/kota dalam bentuk rencana penanganan fakir miskin di daerah dengan berpedoman pada kebijakan, strategi, dan program nasional. Ayat (3) Pemerintah desa melaksanakan penanganan fakir miskin sesuai dengan ketentuan peraturan perundangundangan.

Peraturan Pemerintah Republik Indonesia Nomor 63 Tahun 2013 Tentang Pelaksanaan Upaya Penanganan Fakir Miskin Melalui Pendekatan Wilayah. Pasal 3. Upaya Penanganan Fakir Miskin melalui pendekatan wilayah dimaksudkan untuk:

a. memberikan arah agar Penanganan Fakir Miskin dilakukan secara terpadu, terarah, dan berkesinambungan sehingga dapat meningkatkan derajat kesejahteraan Fakir Miskin; dan

b. memberikan pedoman bagi pengambilan kebijakan yang berpihak kepada peningkatan kesejahteraan Fakir Miskin, berbasiskan wilayah dengan memperhatikan kearifan lokal.

Pasal 4. Upaya Penanganan Fakir Miskin melalui pendekatan wilayah bertujuan:

a. terpenuhinya Kebutuhan Dasar Fakir Miskin agar memperoleh kehidupan yang layak dan bermartabat yang dilaksanakan oleh Menteri, menteri/pimpinan lembaga terkait sesuai dengan tugas dan fungsinya;

10 Sudarsono, Kamus Hukum, Cetakan Keenam, PT. Rineka Cipta, Jakarta, 2009, hlm. 345. 
b. meningkatnya kapasitas dan berkembangnya kemampuan dasar serta kemampuan berusaha bagi Fakir Miskin; dan

c. terentaskannya Fakir Miskin dari kemiskinan.

Pemerintah: ${ }^{11}$

1. proses, cara, perbuatan pemerintah;

2. segala urusan yang dilakukan oleh negara dalam menyelenggarakan kesejahteraan masyarakat dan kepentingan negara.

Peraturan Pemerintah Nomor Nomor 16 Tahun 2015 Tentang Tata Cara Pengumpulan dan Penggunaan Sumbangan Masyarakat Bagi Penanganan Fakir Miskin. Pasal 40 ayat:

(1) Menteri, gubernur, dan bupati/walikota sesuai dengan kewenangannya melakukan pembinaan terhadap pelaksanaan pengumpulan dan penggunaan sumbangan masyarakat bagi kepentingan penanganan fakir miskin sesuai dengan ketentuan peraturan perundang-undangan.

(2) Pembinaan sebagaimana dimaksud pada ayat (1), dilakukan melalui:
a. sosialisasi;
b. komunikasi;
c. informasi; dan/atau
d. edukasi.

Pasal 41 ayat:

(1) Menteri, gubernur, dan bupati/walikota sesuai dengan kewenangannya melakukan pengawasan terhadap pelaksanaan pengumpulan dan penggunaan sumbangan masyarakat bagi kepentingan penanganan fakir miskin.

(2) Dalam melaksanakan pengawasan sebagaimana dimaksud pada ayat (1), Menteri, gubernur, dan bupati/walikota mempunyai tugas:
a. melakukan pengawasan atas pemberian sumbangan masyarakat;
b. menerima laporan dari masyarakat mengenai adanya dugaan penyimpangan pemberian sumbangan masyarakat dan penyaluran dana sumbangan masyarakat.
b. melakukan klarifikasi atas adanya dugaan penyimpangan pemberian sumbangan masyarakat dan penyaluran dana sumbangan masyarakat yang dilaporkan oleh masyarakat; dan

c. mengusulkan sanksi administratif kepada Menteri, gubernur, atau bupati/walikota atas terjadinya penyimpangan pemberian sumbangan masyarakat dan/atau penyaluran dana sumbangan masyarakat.

(3) Masyarakat dapat melakukan pengawasan terhadap pelaksanaan pengumpulan dan penggunaan sumbangan masyarakat bagi kepentingan penanganan fakir miskin sesuai dengan ketentuan peraturan perundang-undangan.

Hukum melindungi kepentingan seseorang dengan cara mengalokasikan suatu kekuasaan kepadanya untuk bertindak dalam rangka kepentingannya tersebut. Pengalokasian kekuasaan ini dilakukan secara teratur dalam arti ditentukan keluasaan dan kedalamannya. Kekuasaan yang demikian itulah yang disebut sebagai "hak". Dengan demikian tidak setiap kekuasaan dalam masyarakat itu bisa disebut sebagai hak, melainkan hanya kekuasaan tertentu saja, yaitu yang diberikan oleh hukum kepada seseorang. ${ }^{12}$

Peraturan Pemerintah Republik Indonesia Nomor 63 Tahun 2013 Tentang Pelaksanaan Upaya Penanganan Fakir Miskin Melalui Pendekatan Wilayah, mengatur mengenai Koordinasi Dan Rencana Aksi. Pasal 39 ayat:

(1) Menteri mengoordinasikan pelaksanaan Penanganan Fakir Miskin pada tingkat nasional.

(2) Koordinasi sebagaimana dimaksud pada ayat (1), meliputi:

a. proses penetapan kriteria Fakir Miskin;

b. pelaksanaan Penanganan Fakir Miskin yang dilaksanakan oleh kementerian/lembaga sesuai dengan tugas dan fungsinya;

c. penyusunan rencana aksi nasional; dan

d. evaluasi pelaksanaan Penanganan Fakir Miskin oleh kementerian/lembaga.

Pasal 40 ayat:

(1) Gubernur mengoordinasikan pelaksanaan Penanganan Fakir Miskin pada tingkat provinsi.

(2) Koordinasi sebagaimana dimaksud pada ayat (1), meliputi:

a. pelaksanaan Penanganan Fakir Miskin yang dilaksanakan oleh satuan kerja

\footnotetext{
${ }^{11}$ Sudarsono, Kamus Hukum, Op. Cit. hlm. 345.
}

\footnotetext{
12 Satjipto Rahardjo, 2006, hlm. 53-54.
} 
perangkat daerah provinsi sesuai dengan tugas dan fungsinya; dan

b. monitoring dan evaluasi hasil pelaksanaan Penanganan Fakir Miskin oleh satuan kerja perangkat daerah provinsi.

Pasal 41 ayat:

(1) Bupati/walikota mengoordinasikan pelaksanaan Penanganan Fakir Miskin pada tingkat kabupaten/kota.

(2) Koordinasi sebagaimana dimaksud pada ayat (1), meliputi:

a. pelaksanaan Penanganan Fakir Miskin yang dilaksanakan oleh satuan kerja perangkat daerah kabupaten/kota sesuai dengan tugas dan fungsinya; dan

b. monitoring dan evaluasi hasil pelaksanaan Penanganan Fakir Miskin oleh satuan kerja perangkat daerah kabupaten/kota.

Peraturan Pemerintah Republik Indonesia Nomor 63 Tahun 2013 Tentang Pelaksanaan Upaya Penanganan Fakir Miskin Melalui Pendekatan Wilayah, mengatur tentang Rencana Aksi Nasional sebagaimana dinyatakan pada Pasal 42 ayat:

(1) Upaya Penanganan Fakir Miskin dilaksanakan secara terencana, terarah, terukur, dan terpadu dengan berdasarkan pada rencana aksi nasional Penanganan Fakir Miskin.

(2) Menteri mengoordinasikan penyusunan rencana aksi nasional sebagaimana dimaksud pada ayat (1), bersama menteri/pimpinan lembaga terkait sesuai tugas dan fungsinya.

(3) Rencana aksi nasional Penanganan Fakir Miskin sebagaimana dimaksud pada ayat (1) merupakan sinkronisasi dan keterpaduan program dan kegiatan antarkementerian/lembaga dalam upaya Penanganan Fakir Miskin.

Data Terpadu untuk Program Penanganan Fakir Miskin (Data Terpadu PPFM) adalah sistem data elektronik yang memuat informasi sosial, ekonomi, dan demografi dari sekitar $40 \%$ rumah tangga dengan status kesejahteraan terendah di Indonesia. Basis Data ini dikelola oleh Pokja Pengelola Data Terpadu Program Penanganan Fakir Miskin yaitu Kementerian Sosial (Kemsos), Kemenko PMK, BPS, Dukcapil Kemendagri, danSekretariat Tim Nasional
Percepatan Penanggulangan Kemiskinan (TNP2K), yang dapat diakses secara gratis oleh berbagai kementerian/lembaga baik di pusat maupun daerah. Data Terpadu PPFM merupakan hasil Pemutakhiran Basis Data Terpadu (PBDT) yang dilakukan pada tahun 2015 oleh Badan Pusat Statistik (BPS). Data Terpadu Program PFM berisi sekitar: 92.994.742 jiwa. $^{13}$

Landasan Hukum:

1. Undang-undang Nomor 13 Tahun 2011 tentang Penanganan Fakir Miskin, Pasal 810: Pendataan fakir miskin, Pasal 11: Penetapan

2. Undang-undang Nomor 14 Tahun 2008 tentang Keterbukaan Informasi Publik, Pasal 2 dan 6: Pengecualian informasi publik

3. Undang-undang Nomor 11 Tahun 2008 tentang Informasi dan Transaksi Elektronik, Pasal 26: Perlindungan hak pribadi

4. PP No. 82 tahun 2012 tentang Sistem dan Transaksi Elektronik, Pasal 15: Kerahasiaan data Pribadi

5. SK Mensos No. 32/HUK/2016 tentang Penetapan Data Terpadu Program Penanganan Fakir Miskin

6. SK Mensos No. 284/HUK/2016 tentan Kelompok Kerja Pengelola Data Terpadu Program Penanganan Fakir Miskin. ${ }^{14}$

Data Terpadu PPFM digunakan untuk memperbaiki kualitas penetapan sasaran program-program perlindungan sosial. Data Terpadu PPFM membantu perencanaan program, memperbaiki penggunaan anggaran dan sumber daya program perlindungan sosial. Dengan menggunakan data dari Data Terpadu PPFM, jumlah dan sasaran penerima manfaat program dapat dianalisis sejak awal perencanaan program. Hal ini akan membantu mengurangi kesalahan dalam penetapan sasaran program perlindungan sosial. Kementerian, Pemerintah Daerah dan Lembaga lain yang menjalankan program penanggulangan kemiskinan dan perlindungan sosial dapat menggunakan data dari Data Terpadu PPFM dengan memperolehnya melalui Pokja Pengelola Data Terpadu PFM tanpa dipungut biaya. ${ }^{15}$

\footnotetext{
13 http://www.tnp2k.go.id/data-and-indicator. Diakses 10/22/2019 11:46 Wita.

14 lbid.

15 lbid.
} 
Kementerian Sosial (Kemensos) menjalankan Program Penanganan Fakir Miskin (PMF) Perdesaan melalui Bantuan Sosial Pangan dan Reguler. Hal ini dilakukan karena angka kemiskinan desa, dua kali lebih besar dibandingkan kota. Direktur Penanganan PMF Perdesaan Kemensos Naziarto memaparkan, data Badan Pusat Statistik (BPS) pada 16 Juli 2018 menunjukkan, persentase jumlah penduduk miskin di Indonesia pada bulan Maret mencapai 25,95 juta orang. Dari angka tersebut, sebanyak 7,02 persen penduduk miskin ada di kota dan 13,20 persen di desa. ${ }^{16}$

Untuk itu, program PFM Perdesaan menjadi hal yang perlu disiapkan seefektif mungkin sehingga pelaksanaannya bisa tepat sasaran. Kemensos secara khusus juga menyelenggarakan kegiatan Evaluasi Pelaksanaan Program Bantuan Sosial Pangan dan Reguler untuk program PFM perdesaan. Kegiatan yang berlangsung di Hotel el-Royale, Jakarta pada 28 November hingga 1 Desember 2018 itu mengundang 445 orang Koordinator Tenaga Kesejahteraan Sosial (Korteks), Kepala Dinas Sosial dari 252 Kabupaten atau Kota, serta perwakilan Dinas Sosial Provinsi dari 11 provinsi yang berada di Wilayah I. Naziarto berharap, kegiatan tersebut bisa menjadi ajang evaluasi dan penyerapan aspirasi sehingga program bisa berjalan lebih optimal ke depannya. "Dengan terselenggaranya kegiatan ini, diharapkan dapat menghadirkan kesepakatan dan pemahaman terhadap bentuk, prosedur dan mekanisme kegiatan Bantuan Sosial Pangan dan Reguler di wilayah kerja Direktorat Penanganan Fakir Miskin Perdesaan serta umpan balik dari daerah untuk perbaikan pelaksanaan kegiatan Bantuan Sosial di masa mendatang," katanya saat memberikan penjelasan teknis di Jakarta. ${ }^{17}$

Tugas dan wewenang pemerintah dalam melaksanakan penanganan fakir miskin wajib dilaksanakan karena sesuai dengan ketentuan Undang-Undang Dasar Negara Republik Indonesia Tahun 1945, negara bertanggung jawab untuk memelihara fakir miskin guna memenuhi kebutuhan dasar yang layak bagi

\footnotetext{
${ }^{16} \mathrm{https}: / /$ www.inews.id/news/nasional. Tangani Fakir Miskin Perdesaan, Kemensos Evaluasi Bantuan Sosial. Diakses 10/23/2019 12:15 Wita.

17 Ibid.
}

kemanusiaan. Untuk melaksanakan tanggung jawab negara diperlukan kebijakan pembangunan nasional yang berpihak pada fakir miskin secara terencana, terarah, dan berkelanjutan dalam penanganan fakir miskin.

\section{PENUTUP}

\section{A. Kesimpulan}

1. Tugas pemerintah dalam melaksanakan penanganan fakir miskin diantaranya memberdayakan pemangku kepentingan dalam penanganan fakir miskin dan memfasilitasi dan mengoordinasikan pelaksanaan kebijakan dan strategi penanganan fakir miskin. Pemerintah Daerah Provinsi bertugas mengawasi dan mengendalikan pelaksanaan kebijakan, strategi, dan program dalam penanganan fakir miskin lintaskabupaten/kota dan mengevaluasi pelaksanaan kebijakan, strategi, dan program penyelenggaraan penanganan fakir miskin lintaskabupaten/kota. Pemerintah Daerah Kabupaten/Kota bertugas memfasilitasi, mengoordinasikan, dan menyosialisasikan pelaksanaan kebijakan, strategi, dan program penyelenggaraan penanganan kemiskinan, dengan memperhatikan kebijakan provinsi dan kebijakan nasional dan melaksanakan pemberdayaan pemangku kepentingan dalam penanganan fakir miskin pada tingkat kabupaten/kota.

2. Wewenang pemerintah dalam melaksanakan penanganan fakir miskin seperti menetapkan kebijakan dan strategi penanganan fakir miskin pada tingkat nasional. Pemerintah daerah provinsi berwenang menetapkan kebijakan, strategi, dan program tingkat provinsi dalam bentuk rencana penanganan fakir miskin di daerah dengan berpedoman pada kebijakan, strategi, dan program nasional. Pemerintah daerah kabupaten/kota berwenang menetapkan kebijakan, strategi, dan program tingkat kabupaten/kota dalam bentuk rencana penanganan fakir miskin di daerah dengan berpedoman pada kebijakan, strategi, dan program nasional. 
Pemerintah desa melaksanakan penanganan fakir miskin sesuai dengan ketentuan peraturan perundangundangan.

\section{B. Saran}

1. Dalam pelaksanaan tugas pemerintah untuk penanganan fakir miskin, pemerintah pusat, pemerintah daerah provinsi dan pemerintah kabupaten/kota perlu melakukan pengawasan dan pengendalian terhadap kebijakan, strategi, serta program dalam penanganan fakir miskin serta mengevaluasi kebijakan, strategi, dan program termasuk menyediakan sarana dan prasarana bagi penanganan fakir miskin.

2. Dalam pelaksanaan kewenangan pemerintah untuk penanganan fakir miskin pemerintah pusat, pemerintah provinsi dan pemerintah kabupaten/kota perlu menetapkan kebijakan dan strategi penanganan fakir miskin dengan berpedoman pada kebijakan, strategi, dan program nasional. Pemerintah desa juga perlu mendukung pelaksanaan penanganan fakir miskin sesuai dengan ketentuan peraturan perundangundangan yang berlaku.

\section{DAFTAR PUSTAKA}

Arifin Noor. Ilmu Sosial Dasar. CV. Pustaka Setia. Bandung. 2007.

Dadang Sufianto . Etika Pemerintahan di Indonesia. Alfabeta. Bandung. 2016.

Hariri Muhwan Wawan. Pengantar Ilmu Hukum, Cet. 1. CV. Pustaka Setia Bandung. 2012.

Hartiningsih Maria, Korupsi Pembusukan Masif Kolektif, (Pengantar Editor) Dalam Maria Hartiningsih (Editor) Korupsi Yang Memiskinkan, Penerbit Buku Kompas, PT. Kompas Media Nusantara, 2011.

Huda Nurul, R.A. Rini Anggraini dan Iwan Rachmad Sutiyono. Peranan Pemerintah Daerah Dalam Penanganan Kemiskinan Berdasarkan Undang Undang No.13 Tahun 2011 Tentang Penanganan Fakir Miskin (Studi di Kabupaten Bondowoso) The Local Government Achieved In Carry On Proverty According To Law Number
13 Of 2011 About Destitute Poor (Study In Bondowoso Distric). Artikel Ilmiah Hasil Penelitian Mahasiswa 2013.

Husni Lalu, Pengantar Hukum Ketenagakerjaan Indonesia, Edisi Revisi, PT. RajaGrafindo, Jakarta, 2008.

Jeddawi Murtir H., Negara Hukum Good Governance dan Korupsi di Daerah, Total Media, Yogyakarta, 2011.

Kencana Inu Syafiie. IImu Pemerintahan Edisi Revisi Kedua. Mandar Maju. Bandung. 2013.

Kencana Inu Syafiie. Ilmu Pemerintahan. Bumi Aksara. Jakarta. 2013.

Leo Agustino. Perihal Ilmu Pemerintahan Sebuah Bahasan Memahami Ilmu Politik. Graha Ilmu. Yogyakarta. 2007.

Mahmud Marzuki Peter, Penelitian Hukum, Edisi Pertama Cetakan ke-2, Kencana Prenada Media Group, Jakarta, 2006.

Marbun SF. Pokok-Pokok Hukum Administrasi Negara. Liberty. Yogyakarta. 1997.

Masriani Tiena Yulies. Pengantar Hukum Indonesia, Cetakan Kelima, Sinar Grafika, Jakarta. 2009.

Nuh Muhammad. Etika Profesi Hukum. CV. Pustaka Setia. Bandung. 2011.

Pemerintah Daerah Kota Sukabumi. Naskah Akademik Rancangan Peraturan Daerah Kota Sukabumi Tentang Penanggulangan Kemiskinan. Kerjasama Antara Pemerintah Daerah Kota Sukabumi Dengan Fakultas Hukum Universitas Katolik Parahyangan Bandung. Sukabumi Tahun 2018.

Pusat Analisis Dan Evaluasi Hukum Nasional Badan Pembinaan Hukum Nasional Kementerian Hukum Dan Ham. Analisis Evaluasi Hukum Dalam Rangka Penanggulangan Kemiskinan. Tahun 2016.

Rahardjo Satjipto, IImu Hukum, Cetakan ke- IV, PT. Citra Aditya Bakti, Bandung, 2006.

Raharjo Satjipto. Hukum dan Perubahan Sosial Suatu Tinjauan Teoretis Serta Pengalaman-Pengalaman di Indonesia. Cetakan Ketiga Genta Publishing. Yogyakarta. 2009.

Sadjijono. Polri Dalam Perkembangan Hukum Di Indonesia, (Editor) M. Khoidin, LaksBang PRESSindo, Yogyakarta. 2008. 
Silondae Akbar Arus dan Wirawan B. Ilyas. Pokok-Pokok Hukum Bisnis. Salemba Empat. Jakarta. 2011.

Sitepu Anwar. Analisis Efektifitas Kelompok Usaha Bersama Sebagai Instrumen Program Penanganan Fakir Miskin Efectivity Analysis Collective Business Group (Cbg) As An Instrument In Management Program of The Poor. Sosio Informa Vol. 2, No. 01, Januari April, Tahun 2016. Kesejahteraan Sosial.

Sekretariat Dewan Perwakilan Rakyat Daerah Daerah Istimewa Yogyakarta. Naskah Akademik Dan Rancangan Peraturan Daerah Tentang Penanggulangan Kemiskinan. Tahun 2018.

Siswanto Sunarno, Hukum Pemerintahan Daerah di Indonesia, Cetakan Ketiga. Sinar Grafika. Jakarta. 2009.

Soekanto Soerjono dan Sri Mamudji, Penelitian Hukum Normatif Suatu Tinjauan Singkat, PT Raja Grafindo Persada, Jakarta. 1995.

Sudarsono, Pengantar Ilmu Hukum, Cetakan Kelima, PT. Rineka Cipta, Jakarta, 2007.

Sudarsono, Kamus Hukum, Cetakan Keenam, PT. Rineka Cipta, Jakarta, 2009.

Suharto Edi. Kemiskinan dan Perlindungan Sosial di Indonesia. Alfabeta. Bandung. 2103.

Supriadi dan Alimudin, Hukum Perikanan Indonesia, Cetakan Pertama, Sinar Grafika, Jakarta, 2011.

Thontowi Jawahir. Pengantar Ilmu Hukum. Pustaka Fahima. Yogjakarta. 2007.

Tutik Triwulan Titik, Pengantar Hukum Perdata di Indonesia, Cetakan Pertama, Jakarta, 2006.

Usman, Aspek-Aspek Hukum Perbankan di Indonesia. Penerbit Gramedia Pustaka Utama. Jakarta. 2001.

\section{Internet}

http://www.tnp2k.go.id/data-and-indicator.

Diakses 10/22/2019 11:46 Wita.

https://www.inews.id/news/nasional. Tangani Fakir Miskin Perdesaan, Kemensos Evaluasi Bantuan Sosial. Diakses 10/23/2019 12:15 Wita.

\section{Peraturan Perundang-Undangan}

Undang Undang Nomor 13 Tahun 2011 tentang Penaganan Fakir Miskin.
Undang-Undang Nomor 11 Tahun 2009 Tentang Kesejahteraan Sosial.

Peraturan Pemerintah Nomor 63 Tahun 2013 Tentang Pelaksanaan Upaya Penanganan Fakir Miskin Melalui Pendekatan Wilayah.

Peraturan Pemerintah Nomor Nomor 16 Tahun 2015 Tentang Tata Cara Pengumpulan dan Penggunaan Sumbangan Masyarakat Bagi Penanganan Fakir Miskin. 